\title{
Characterization of novel psychrophilic clostridia from an Antarctic microbial mat: description of Clostridium frigoris sp. nov., Clostridium lacusfryxellense sp. nov., Clostridium bowmanii sp. nov. and Clostridium psychrophilum sp. nov. and reclassification of Clostridium laramiense as Clostridium estertheticum subsp. laramiense subsp. nov.
}

Stefan Spring, Birgit Merkhoffer, Norbert Weiss, Reiner M. Kroppenstedt, Hans Hippe and Erko Stackebrandt

Correspondence Stefan Spring ssp@dsmz.de
DSMZ - Deutsche Sammlung von Mikroorganismen und Zellkulturen, Mascheroder Weg 1b, 38124 Braunschweig, Germany

Taxonomic studies were performed on four strains (D-1/D-an/II ${ }^{\top}, \mathrm{C} / \mathrm{C}-\mathrm{an} / \mathrm{B} 1^{\top}, \mathrm{A}-1 / \mathrm{C}-\mathrm{an} / \mathrm{C} 1^{\top}$ and A-1/C-an $/ \mathrm{I}^{\top}$ ) of anaerobic, Gram-positive, spore-forming bacteria originally isolated from a mat sample retrieved from a shallow, moated area around Lake Fryxell, an Antarctic freshwater lake. Phylogenetic analyses based on 16S rRNA gene sequence data indicated that these strains are affiliated with cluster I clostridia and form a coherent group with Clostridium estertheticum and Clostridium laramiense. Similarity values among 16S rRNA gene sequences within this assemblage ranged between $96 \cdot 7$ and $99 \cdot 8 \%$. Despite the close phylogenetic relationship, several distinguishing phenotypic traits were found among the novel strains using a polyphasic approach. All strains were psychrophilic, but the temperature optimum for growth differed markedly, ranging from 4 to $16{ }^{\circ} \mathrm{C}$. In addition, substrate utilization patterns, fermentation end products, cellular fatty acid profiles and morphological traits enabled a clear differentiation between the strains. DNA-DNA hybridization experiments revealed that each of the four novel strains represents a distinct species, with DNA-DNA similarity values to related strains in the range $16-62 \%$. In contrast, the type strains of $C$. estertheticum and C. laramiense shared $79 \%$ DNA-DNA similarity, indicating a close relationship at the species level. On the basis of genetic and phenotypic properties, it is proposed to designate four novel species of the genus Clostridium to harbour the newly isolated strains: Clostridium frigoris sp. nov. (type strain D-1/D-an/II $=\mathrm{DSM}$ $14204^{\top}=$ ATCC BAA $-579^{\top}$ ), Clostridium lacusfryxellense sp. nov. (type strain C/C-an/ $\mathrm{B} 1^{\top}=\mathrm{DSM} 14205^{\top}=$ ATCC BAA $-580^{\top}$ ), Clostridium bowmanii sp. nov. (type strain A-1/C-an/ $\mathrm{C} 1^{\top}=\mathrm{DSM} 14206^{\top}=$ ATCC BAA-581 ${ }^{\top}$ ) and Clostridium psychrophilum sp. nov. (type strain A-1/C-an $/ /^{\top}=D S M 14207^{\top}=$ ATCC BAA $-582^{\top}$ ). It is also proposed to unite C. laramiense and C. estertheticum under $C$. estertheticum. The subspecies $C$. estertheticum subsp. laramiense subsp. nov. is established, represented by strain ATCC $51254^{\top}$ (=DSM $14864^{\top}$ ). The type strain of C. estertheticum subsp. estertheticum remains NCIMB $12511^{\top}\left(=\mathrm{DSM} 8809^{\top}\right)$.

Published online ahead of print on 29 November 2002 as DOI 10.1099/ijs.0.02554-0.

The GenBank/EMBL/DDBJ accession numbers for the $16 \mathrm{~S}$ rRNA gene sequences of C. laramiense ATCC $51254^{\top}$ and strains DSM $14204^{\top}$ (clone

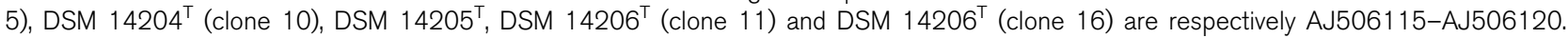

Graphs showing the temperature dependence of growth of the novel isolates displayed as Ratkowsky-type plots are available as supplementary material in IJSEM Online. 


\section{INTRODUCTION}

With few exceptions, most of the currently recognized Clostridium species have been isolated from moderate environments. The finding of abundant clostridia in a microbial mat located in the moated periphery of a perennial frozen lake was therefore quite unexpected. In the study of Brambilla et al. (2001) concerning the microbial community of a mat sample from Lake Fryxell, Antarctica, it was reported that more than $10 \%$ of the cloned 16S rRNA gene sequences and five of the isolates obtained belonged to the cluster I clostridia as defined by Collins et al. (1994). It can be assumed that phylogenetic diversity within the isolated DNA and the isolates is representative of the autochthonous microbial flora of this habitat, due to the isolated geographical location of the studied site, which is far away from any considerable anthropogenic impact. However, it cannot be excluded that, during transportation of the mat sample from Antarctica to the DSMZ laboratory, the abundance of clostridia increased due to the durability of formed endospores compared with vegetative cells of more fastidious species.

In the course of the study on the Lake Fryxell microbial mat, it turned out that most of the cloned 16S rRNA gene sequences and four of the five isolates that were affiliated to the cluster I clostridia were phylogenetically most closely related to Clostridium estertheticum, a psychrophilic species that was originally isolated from spoiled vacuum-packed refrigerated beef (Collins et al., 1992). Here, results of a detailed taxonomic study on four bacterial strains, previously isolated from an Antarctic microbial mat, and comparisons with strains of phylogenetically related psychrophilic clostridia are presented.

\section{METHODS}

Bacterial strains. Strains D-1/D-an/ $/ \mathrm{II}^{\mathrm{T}}$ (=DSM $\left.14204^{\mathrm{T}}\right)$, C/C-an/ $\mathrm{B}^{\mathrm{T}}\left(=\mathrm{DSM} 14205^{\mathrm{T}}\right), \mathrm{A}-1 / \mathrm{C}-\mathrm{an} / \mathrm{Cl}^{\mathrm{T}}\left(=\mathrm{DSM} 14206^{\mathrm{T}}\right)$ and $\mathrm{A}-1 / \mathrm{C}-$ an $/ \mathrm{I}^{\mathrm{T}}\left(=\mathrm{DSM} 14207^{\mathrm{T}}\right)$ were isolated from a microbial mat located at the shallow, moated area of Lake Fryxell, McMurdo Dry Valley Region, Antarctica, as described previously (Brambilla et al., 2001). C. estertheticum DSM $8809^{\mathrm{T}}$ and Clostridium laramiense ATCC $51254^{\mathrm{T}}$ were included for comparison. Unless otherwise stated, all strains were grown anaerobically at $8{ }^{\circ} \mathrm{C}$ in Wilkins-Chalgren broth (Oxoid). The anaerobic culture technique of Hungate (1950) was used throughout the study for culturing and maintenance of strains.

\begin{abstract}
Morphological, physiological and biochemical characterization. Cell dimensions, the presence of spores and motility were examined by phase-contrast microscopy (Axiophot; Zeiss). The Gram reaction was tested with exponentially growing cultures using the Merck Gram-colour staining kit. For detection of spores, a low-nutrient medium was used based on DSMZ medium 63 (DSMZ, 2001), which was modified by adding yeast extract and trypticase peptone, each at a concentration of $2 \mathrm{~g} \mathrm{l}^{-1}$, to give modified M63 medium. To obtain photomicrographs of sporulating bacteria, slides were thinly coated with water agar $(2 \%, w / v)$. Flagellation was studied using the staining method of Heimbrook et al. (1989).
\end{abstract}

The $\mathrm{pH}$ range and optimum for growth were determined in buffered Wilkins-Chalgren broth by adjusting the final $\mathrm{pH}$ to values between
4.5 and 8.5 with sterile $\mathrm{NaOH}$ or $\mathrm{HCl}$. The following buffers were used (each at $10 \mathrm{mM}$ ): trisodium citrate ( $\mathrm{pH} 4 \cdot 5-5 \cdot 5)$, MES ( $\mathrm{pH} \mathrm{5 \cdot 5-}$ $6 \cdot 5$ ), PIPES (pH $6 \cdot 8$ and $7 \cdot 0$ ), MOPS ( $\mathrm{pH} 7 \cdot 2$ and $7 \cdot 4$ ), HEPES $(\mathrm{pH} 7 \cdot 6$ and $7 \cdot 8)$ and Tris $(\mathrm{pH} 7 \cdot 8-8 \cdot 5)$. For determination of the temperature range and optimum, cultures were incubated with constant shaking in a temperature gradient incubator (TN-3; Toyo Kagaku Sangyo). Hungate tubes filled with inoculated anaerobic medium were kept in the temperature gradient $\left(3 \cdot 0-30 \cdot 5{ }^{\circ} \mathrm{C}\right)$ for at least 10 days. The growth response was monitored by measuring $\mathrm{OD}_{600}$ with a UV/vis spectrophotometer (Ultraspec II; LKB) equipped for the direct measurement of turbidity in Hungate tubes.

Fermentation of 24 different carbohydrates and hydrolysis of gelatin and starch were tested essentially as described by Holdeman et al. (1977), with the exception that the following basal media were used: diluted Wilkins-Chalgren broth was used for strains DSM $14204^{\mathrm{T}}$ ( $1 / 10$ concentration) and DSM $14205^{\mathrm{T}}$ (1/2 concentration); PY broth [DSMZ medium 104 (DSMZ, 2001) without glucose, Tween 80 and only $1 \mathrm{~g}$ yeast extract $\mathrm{l}^{-1}$ ] was used for testing strains DSM $14206^{\mathrm{T}}$, DSM $14207^{\mathrm{T}}$, C. estertheticum DSM $8809^{\mathrm{T}}$ and C. laramiense ATCC $51254^{\mathrm{T}}$.

Analyses of fermentation products. Alcohols and volatile and non-volatile fatty acids formed after growth in peptone broth plus glucose (the composition of the medium used was the same as in the carbohydrate utilization tests) were analysed by GC according to Holdeman et al. (1977), with the modifications described by Steer et al. (2001). As this analytical equipment was not appropriate for detection of formate, this compound was quantified by a colorimetric assay (Lang \& Lang, 1972).

Chemotaxonomic characterization. The interpeptide bridge in the cell wall peptidoglycan was analysed using the method described by Schleifer \& Kandler (1972). Cell wall hydrolysates were separated by one- or two-dimensional chromatography on cellulose thin layers (Merck).

Cellular fatty acid patterns were determined from cells grown to stationary phase in Wilkins-Chalgren broth. Fatty acid methyl esters were obtained from $40 \mathrm{mg}$ (wet wt) cells by saponification, methylation and extraction as described previously (Kämpfer \& Kroppenstedt, 1996; Kroppenstedt, 1985; Miller, 1982). The fatty acid methyl ester mixtures were separated by an automated GC system (model 5890 Series II and 7673 autosampler; Agilent) controlled by MIS software (Microbial ID). Peaks were integrated automatically and fatty acid names and percentages were determined using the Microbial Identification standard software (Sasser, 1990).

Analysis of DNA and phylogeny. Genomic DNA for the determination of DNA base composition and DNA-DNA hybridization studies was isolated using a French pressure cell and purified by chromatography on hydroxyapatite as described by Cashion et al. (1977). The G + C content was determined by reversed-phase HPLC of nucleosides according to Mesbah et al. (1989). DNA-DNA hybridization studies were carried out according to the method of De Ley et al. (1970) with the modification described by Huß et al. (1983), using a Gilford System model 2600 spectrophotometer equipped with a Gilford model 2527-R thermoprogrammer and plotter. Renaturation rates were computed with the TRANSFER.BAS program (Jahnke, 1992). Ribotyping of cultures was done as described previously using the Qualicon RiboPrinter system (DuPont) with PvuII as the restriction enzyme (Bruce, 1996).

Genomic DNA extraction, PCR-mediated amplification of the 16S rDNA, purification of PCR products and electrophoresis of sequence reactions were done as described previously (Rainey et al., 1996). The ARB program package developed by O. Strunk, W. Ludwig and others at the Technische Universität München, Munich, Germany was used 
for phylogenetic analysis of the determined sequences. The database of SSU rRNA sequences used and phylogeny programs are available at http://www.arb-home.de.

\section{RESULTS AND DISCUSSION}

\section{Morphological characteristics}

Cells of the novel strains (DSM $14204^{\mathrm{T}}$, DSM $14205^{\mathrm{T}}$, DSM $14206^{\mathrm{T}}$ and DSM $14207^{\mathrm{T}}$ ) isolated from the Lake Fryxell microbial mat had an appearance typical of representatives of the cluster I clostridia. The morphologies and dimensions observed were compared with cells of C. estertheticum DSM $8809^{\mathrm{T}}$ and C. laramiense ATCC $51254^{\mathrm{T}}$. Morphological traits shared by all strains within this group were as follows: dimensions averaged $1-2 \mu \mathrm{m}$ in width and 2-8 $\mu \mathrm{m}$ in length; Gram-staining was predominantly positive in young cultures, with Gram-negative cells found occasionally in older cultures; cells were motile by flagella that were mainly arranged peritrichously, but with a tendency to accumulate at both cell poles; and endospores were formed terminally or subterminally. Colonies of these strains appeared on Columbia blood-agar plates (Becton-Dickinson) after 14-30 days anaerobic incubation. They had a diameter of 1-2 mm, were round with often coarsely granulated margins, slightly raised, cream-white to greyish, semitransparent to opaque and smooth.

Despite the resemblance of morphotypes within this group, several distinguishing traits were observed, allowing most strains to be differentiated. Strains DSM $14206^{\mathrm{T}}$ and DSM $14207^{\mathrm{T}}$ had a strong tendency to form filamentous cells on agar plates, which frequently reached a length of more than $30 \mu \mathrm{m}$, whereas, in cultures of strains DSM $14204^{\mathrm{T}}$, DSM $14205^{\mathrm{T}}$, C. estertheticum DSM $8809^{\mathrm{T}}$ and C. laramiense ATCC $51254^{\mathrm{T}}$, this characteristic was less pronounced (Fig. 1). Dimensions of cells of each strain are listed in the species descriptions below. The spore shape, spore position and the tendency to form spores also showed considerable variation among the strains of this group. None of the studied strains sporulated in the Wilkins-Chalgren broth routinely used for cultivation. C. estertheticum DSM $8809^{\mathrm{T}}$ and C. laramiense ATCC $51254^{\mathrm{T}}$ showed good sporulation in reinforced clostridial medium (Merck) after 2-4 weeks incubation at $8{ }^{\circ} \mathrm{C}$. Endospores were mainly ellipsoidal and located at a subterminal to central position. Swelling of the sporangium was not observed. Spore formation in these strains was, however, variable and terminal spores in swollen sporangia were frequently observed in modified M63 medium. The latter type of spore formation is in line with the original description given for spores of C. laramiense (Kalchayanand et al., 1993). Strains isolated from the Antarctic microbial mat sporulated only in modified M63 medium. Sporulation in strains DSM $14205^{\mathrm{T}}$, DSM $14206^{\mathrm{T}}$ and DSM $14207^{\mathrm{T}}$ required about 3 weeks incubation at their respective optimal growth temperature and the frequency of sporeforming cells was quite low. In contrast, strain DSM $14204^{\mathrm{T}}$ showed good sporulation after 10 days incubation. Endospores formed by strains DSM $14204^{\mathrm{T}}$, DSM $14205^{\mathrm{T}}$ and DSM $14206^{\mathrm{T}}$ were mainly spherical and in a terminal position, but ellipsoidal spores in a subterminal position were also sometimes observed. Spores of strain DSM $14207^{\mathrm{T}}$, on the other hand, were mainly ellipsoidal and in a subterminal position.

\section{Physiology}

The temperature profiles of the novel isolates reflect their isolation from a permanently cold habitat (maximum temperatures at the Lake Fryxell site do not normally exceed $6^{\circ} \mathrm{C}$ ). All strains were true psychrophiles according to the definition given by Morita (1975), which states that the optimum growth temperature of a psychrophile should be at or below $15^{\circ} \mathrm{C}$ and the upper temperature limit around or below $20^{\circ} \mathrm{C}$. The isolation of psychrophiles from cold habitats is, however, not self-evident, and numerous strains were isolated from the studied Antarctic microbial mat that have temperature optima between 25 and $30^{\circ} \mathrm{C}$ or even above (Frühling et al., 2002; B. Tindall, personal communication). The lowest temperature optimum $\left(4{ }^{\circ} \mathrm{C}\right)$ was determined for strain DSM $14207^{\mathrm{T}}$. Growth of this strain was inhibited at temperatures above $10^{\circ} \mathrm{C}$; this strain therefore represents the most psychrophilic clostridium known so far. Strain DSM $14204^{\mathrm{T}}$ had a temperature optimum of $5-7^{\circ} \mathrm{C}$ (upper growth limit $11^{\circ} \mathrm{C}$ ), strain DSM $14205^{\mathrm{T}}$ had a temperature optimum of $9-11^{\circ} \mathrm{C}$ (upper growth limit $15^{\circ} \mathrm{C}$ ) and strain DSM $14206^{\mathrm{T}}$ had a temperature optimum of $12-15{ }^{\circ} \mathrm{C}$ (upper growth limit $20^{\circ} \mathrm{C}$ ). Comparable temperature profiles within the genus Clostridium have been reported only for C. estertheticum (Collins et al., 1992), C. laramiense (Kalchayanand et al., 1993) and Clostridium vincentii (Mountfort et al., 1997), with respective temperature optima of 6-8 (this study), 15 and $12{ }^{\circ} \mathrm{C}$. To illustrate and compare the temperature profiles of the studied strains, the data obtained were plotted according to the square-root model proposed by Ratkowsky et al. (1982) to describe the temperature dependence of growth in bacteria (available as supplementary material in IJSEM Online). According to the Ratkowsky model, the relationship between the square root of the growth rate and the absolute temperature (in Kelvin) is linear from the minimum temperature at which growth is observed to just below the optimum temperature for growth. Although it was found that this relationship cannot be used to predict precisely the minimum temperature at which the growth rate is zero, it can be applied to determine growth rates at intermediate temperatures. This is especially useful if psychrophiles are studied, because generation times at temperatures near the minimum may become very long and certain media could freeze at temperatures below $0{ }^{\circ} \mathrm{C}$. Interestingly, an extrapolation of the linear graphs obtained by applying the Ratkowsky model to the determined growth rates at suboptimal temperatures revealed that strain DSM $14205^{\mathrm{T}}$ has the lowest predicted temperature limit of all strains studied $\left(-43^{\circ} \mathrm{C}\right)$. This value may be only 

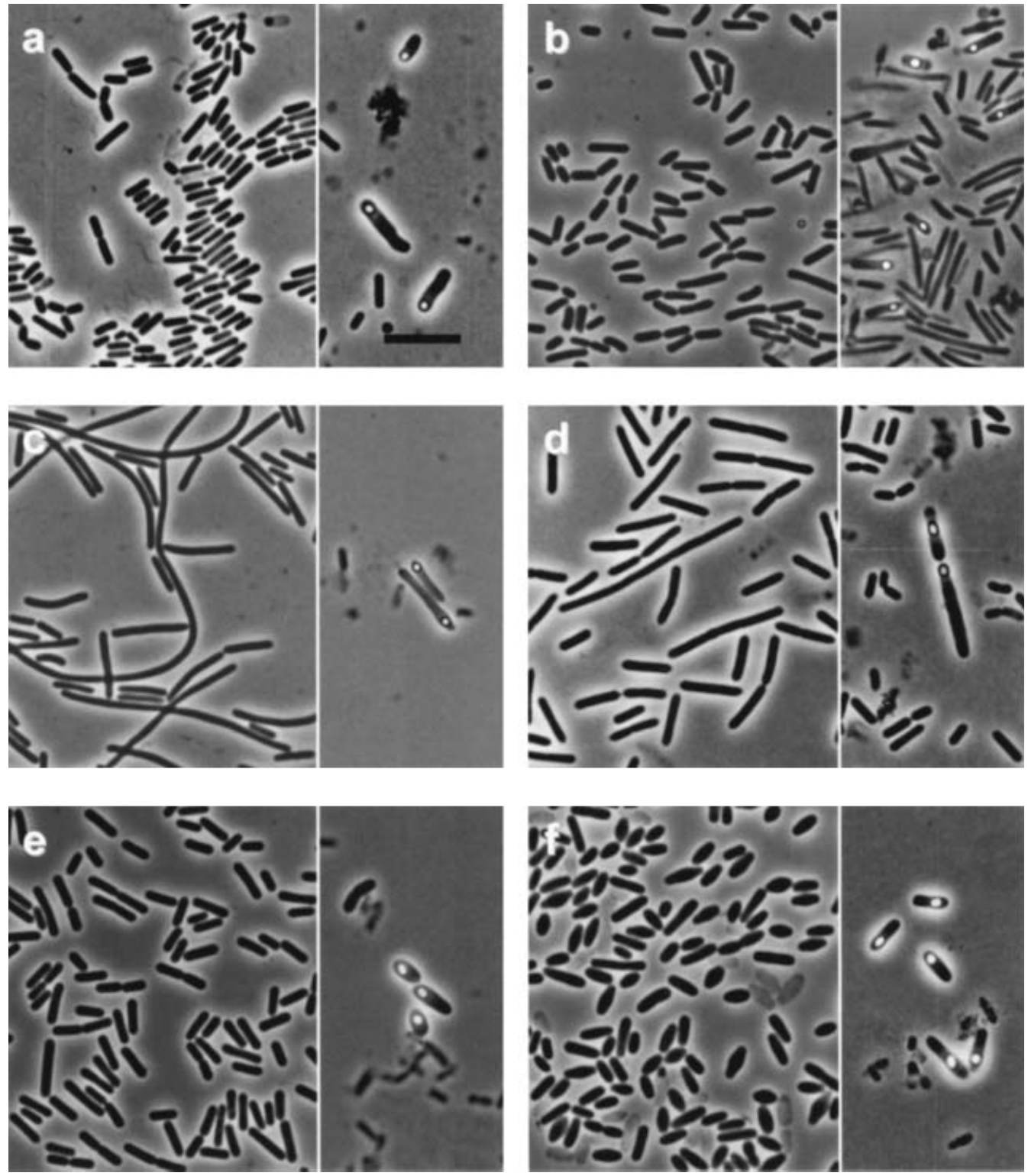

Fig. 1. Phase-contrast micrographs of strains DSM $14204^{\top}$ (a), DSM $14205^{\top}$ (b), DSM $14206^{\top}$ (c) and DSM $14207^{\top}$ (d), C. laramiense ATCC $51254^{\top}$ (e) and C. estertheticum DSM $8809^{\top}$ (f). On the left-hand side of each panel, vegetative cells grown on agar plates are shown; on the right-hand side, sporulating cells of the respective strains are shown, which were cultured either in modified M63 medium ( $a-d$ ) or reinforced clostridial medium (e, f). Bar, $10 \mu$ m (applies to all parts).

of theoretical interest, but it is noteworthy that strain DSM $14207^{\mathrm{T}}$, which has the lowest temperature optimum of all strains, has a much higher predicted temperature minimum $\left(-6^{\circ} \mathrm{C}\right)$. This discrepancy is due to the difference in the decrease of growth rate constants at suboptimal temperatures; when represented graphically, a steeper slope is observed with strain DSM $14207^{\mathrm{T}}$ than with strain DSM $14205^{\mathrm{T}}$. It could be interesting to compare the temperature profiles of other known psychrophiles with that of strain DSM $14205^{\mathrm{T}}$ to determine which micro-organism has the lowest theoretical temperature limit.
The $\mathrm{pH}$ range for growth of the novel isolates was quite narrow. Growth of strain DSM $14204^{\mathrm{T}}$ occurred between pH $5 \cdot 5$ and $7 \cdot 5$ (optimum: $6 \cdot 8-7 \cdot 2$ ), strain DSM $14205^{\mathrm{T}}$ grew between pH $6 \cdot 0$ and $7 \cdot 3$ (optimum: $6 \cdot 6-7 \cdot 1$ ), strain DSM $14206^{\mathrm{T}}$ between pH $5 \cdot 6$ and $7 \cdot 4$ (optimum: $6 \cdot 8-7 \cdot 2$ ) and strain DSM $14207^{\mathrm{T}}$ between $\mathrm{pH} 5 \cdot 5$ and $7 \cdot 5$ (optimum: $6 \cdot 5-7 \cdot 0)$. The $\mathrm{pH}$ range for C. estertheticum DSM $8809^{\mathrm{T}}$ was also determined; growth of this strain occurred at

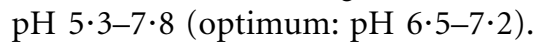

Under optimal growth conditions, the mean generation 
times of strains DSM $14204^{\mathrm{T}}$, DSM $14205^{\mathrm{T}}$, DSM $14206^{\mathrm{T}}$ and DSM $14207^{\mathrm{T}}$ were respectively $13 \cdot 0,10 \cdot 7,8 \cdot 4$ and $33 \cdot 9$ h. The doubling time of C. estertheticum DSM $8809^{\mathrm{T}}$ was $14 \cdot 2 \mathrm{~h}$.

Substrate utilization patterns were determined for the novel strains from the Lake Fryxell microbial mat and compared with results obtained for C. estertheticum DSM $8809^{\mathrm{T}}$ and C. laramiense ATCC $51254^{\mathrm{T}}$. All of the strains tested were saccharolytic and could utilize fructose, glucose, sucrose, xylose and inulin, but gelatin was not hydrolysed. It should be noted that, in contrast to our own results, in the original description of C. laramiense, the utilization of inulin and xylose was reported to be negative (Kalchayanand et al., 1993). In Table 1, an overview of the substrate utilization patterns of all studied strains is given. From these results, it can be concluded that all strains represent saccharolytic clostridia and can be

Table 1. Differential characteristics of the four novel isolates, C. laramiense and C. estertheticum

Strains: 1, C. frigoris sp. nov. DSM $14204^{\mathrm{T}}$; 2, C. lacusfryxellense sp. nov. DSM $14205^{\mathrm{T}}$; 3, C. bowmanii sp. nov. DSM $14206^{\mathrm{T}}$; 4, C. psychrophilum sp. nov. DSM $14207^{\mathrm{T}}$; 5, C. laramiense ATCC $51254^{\mathrm{T}} ; 6$, C. estertheticum DSM $8809^{\mathrm{T}}$. Substrate utilization was determined by the production of acid and gas. ++ , Pronounced production of acid and gas (equal or more compared with medium supplemented with glucose); +, medium production of acid and gas; w, weak production of acid and gas; -, no significant production of acid and gas (comparable to cultures grown in medium lacking glucose). All strains were positive for the utilization of fructose, glucose, inulin and xylose. All strains were negative for the hydrolysis of gelatin.

\begin{tabular}{|c|c|c|c|c|c|c|}
\hline Characteristic & 1 & 2 & 3 & 4 & 5 & 6 \\
\hline Spore shape $e^{\star}$ & $\mathrm{s}$ & $\mathrm{s}$ & $\mathrm{s}$ & $\mathrm{E}$ & $\mathrm{E}$ & $\mathrm{E}$ \\
\hline Spore location $\dagger$ & $\mathrm{T}$ & $\mathrm{T}$ to $\mathrm{ST}$ & $\mathrm{T}$ to $\mathrm{ST}$ & ST to $\mathrm{T}$ & ST to $\mathrm{T}$ & ST to $\mathrm{C}$ \\
\hline Temperature optimum $\left({ }^{\circ} \mathrm{C}\right)$ & $5-7$ & $8-12$ & $12-16$ & 4 & 15 & 6-8 \\
\hline pH optimum & $6 \cdot 8-7 \cdot 2$ & $6 \cdot 5-7 \cdot 1$ & $6 \cdot 6-7 \cdot 2$ & $6 \cdot 5-7 \cdot 0$ & $6 \cdot 5$ & $6 \cdot 5-7 \cdot 2$ \\
\hline \multicolumn{7}{|l|}{ Utilization of: } \\
\hline Amygdalin & + & + & - & - & - & - \\
\hline Arabinose & + & - & - & + & $+(-)^{a_{\ddagger}}$ & + \\
\hline Cellobiose & ++ & ++ & - & + & $+(-)^{a}$ & $\mathrm{w}(+)^{b}$ \\
\hline Galactose & + & ++ & + & - & + & + \\
\hline Glycogen & ++ & + & - & - & + & - \\
\hline Inositol & $\mathrm{w}$ & + & - & - & + & + \\
\hline Inulin & + & ++ & ++ & + & $+(-)^{a}$ & ++ \\
\hline Lactose & + & + & - & - & - & - \\
\hline Maltose & + & - & ++ & + & + & + \\
\hline Mannitol & - & + & - & - & + & + \\
\hline Mannose & ++ & - & ++ & ++ & ++ & ++ \\
\hline Melezitose & - & + & - & - & - & - \\
\hline Melibiose & + & ++ & - & - & ++ & + \\
\hline Raffinose & + & ++ & - & - & + & ++ \\
\hline Rhamnose & + & - & - & - & + & + \\
\hline Ribose & $\mathrm{w}$ & + & $\mathrm{w}$ & - & - & - \\
\hline Salicin & + & ++ & + & - & + & + \\
\hline Sorbitol & - & - & - & - & ++ & + \\
\hline Starch & + & + & - & - & + & $\mathrm{w}(+)^{b}$ \\
\hline Sucrose & + & ++ & ++ & ++ & ++ & ++ \\
\hline Trehalose & ++ & ++ & + & ++ & - & - \\
\hline Xylose & + & ++ & ++ & + & $+(-)^{a}$ & ++ \\
\hline Hydrolysis of starch & - & - & - & - & + & $\mathrm{w}(+)^{b}$ \\
\hline$\beta$-Haemolysis & - & - & - & - & + & - \\
\hline Non-gaseous fermentation products $\S$ & $\mathrm{B}, \mathrm{f}, \mathrm{l}, \mathrm{a}, 2$ & $\mathrm{~B}, \mathrm{~F}, \mathrm{a}, 1,2$ & $\mathrm{~B}, \mathrm{~A}, \mathrm{f}, 2,1,4$ & $\mathrm{~L}, 2,4, \mathrm{~b}$ & $\mathrm{~B}, 4, \mathrm{l}, \mathrm{a}, \mathrm{f}, 2$ & B, A, f, $1,4,2$ \\
\hline
\end{tabular}

${ }^{\star}$ E, Ellipsoidal; s, spherical.

$\dagger \mathrm{C}$, Central; ST, subterminal; T, terminal.

$\ddagger$ Data (in parentheses) that differ from results obtained in this study were taken from: $a$, Kalchayanand et al. (1993); $b$, Collins et al. (1992). \$The sequence of fermentation products listed reflects decreasing concentration; capitals indicate concentrations above $10 \mathrm{mM}$. Fermentation products produced in only small amounts $(<1 \mathrm{mM})$ were not considered. Abbreviations: a, acetic acid; $b$, butyric acid; $f$, formic acid; 1 , lactic acid; 2, ethanol; 4, 1-butanol. 
Table 2. Cellular fatty acid compositions of the four novel isolates, C. laramiense and C. estertheticum

Strains: 1, C. frigoris sp. nov. DSM $14204^{\mathrm{T}}$; 2, C. lacusfryxellense sp. nov. DSM $14205^{\mathrm{T}}$; 3, C. bowmanii sp. nov. DSM $14206^{\mathrm{T}}$; 4 , C. psychrophilum sp. nov. DSM $14207^{\mathrm{T}}$; 5, C. laramiense ATCC $51254^{\mathrm{T}} ; 6$, C. estertheticum DSM $8809^{\mathrm{T}}$. Values are percentages of total fatty acids. Major fatty acids $(>5 \%)$ are in given in bold. Spaces indicate that the fatty acid was not detected. Abbreviations: cyc, cyclopropane; dma, dimethylacetal; ECL, equivalent chain length; WiC, Wilkins-Chalgren medium.

\begin{tabular}{|c|c|c|c|c|c|c|c|c|}
\hline ECL & Fatty acid & 1 & 2 & 3 & 4 & 5 & \multicolumn{2}{|c|}{6} \\
\hline $13 \cdot 899$ & $14: 1 \omega 9 c$ & & $0 \cdot 2$ & $0 \cdot 3$ & $0 \cdot 7$ & & & \\
\hline $14 \cdot 000$ & $14: 0$ & $17 \cdot 2$ & $17 \cdot 8$ & $19 \cdot 7$ & $19 \cdot 5$ & $24 \cdot 7$ & $28 \cdot 4$ & $28 \cdot 3$ \\
\hline $14 \cdot 777-14 \cdot 783$ & Unknown & $7 \cdot 5$ & $4 \cdot 4$ & $4 \cdot 0$ & $4 \cdot 3$ & $8 \cdot 9$ & $8 \cdot 0$ & $4 \cdot 3$ \\
\hline $15 \cdot 909$ & $16: 1 \omega 11 c$ & $8 \cdot 7$ & $5 \cdot 6$ & $8 \cdot 9$ & $10 \cdot 0$ & $8 \cdot 6$ & $7 \cdot 0$ & $7 \cdot 7$ \\
\hline $16 \cdot 000$ & $16: 0$ & $11 \cdot 1$ & $5 \cdot 7$ & $12 \cdot 7$ & $9 \cdot 2$ & $8 \cdot 3$ & $8 \cdot 6$ & $8 \cdot 4$ \\
\hline $16 \cdot 242$ & $16: 1 \omega 7 c \mathrm{dma}$ & $1 \cdot 3$ & $2 \cdot 9$ & $2 \cdot 7$ & $1 \cdot 3$ & $1 \cdot 3$ & $1 \cdot 4$ & $0 \cdot 9$ \\
\hline $16 \cdot 288$ & $16: 1 \omega 9 c \mathrm{dma}$ & $21 \cdot 1$ & $21 \cdot 5$ & $16 \cdot 3$ & $17 \cdot 3$ & $20 \cdot 9$ & $22 \cdot 1$ & $22 \cdot 8$ \\
\hline $16 \cdot 472$ & $16: 0 \mathrm{dma}$ & & $0 \cdot 3$ & $0 \cdot 5$ & $0 \cdot 3$ & & & \\
\hline $17 \cdot 771$ & $18: 1 \omega 9 c$ & $0 \cdot 8$ & $0 \cdot 7$ & $0 \cdot 6$ & $1 \cdot 7$ & $0 \cdot 7$ & $0 \cdot 7$ & $0 \cdot 4$ \\
\hline $17 \cdot 825$ & Unknown & & $0 \cdot 4$ & $0 \cdot 8$ & $0 \cdot 4$ & & & \\
\hline $18 \cdot 000$ & $18: 0$ & $1 \cdot 1$ & $0 \cdot 3$ & $0 \cdot 3$ & $1 \cdot 2$ & & & \\
\hline $18 \cdot 226$ & $18: 1 \omega 9 c \mathrm{dma}$ & & $0 \cdot 4$ & $0 \cdot 1$ & $0 \cdot 9$ & $0 \cdot 5$ & $0 \cdot 5$ & $0 \cdot 3$ \\
\hline
\end{tabular}

${ }^{\star}$ Data from Wilde et al. (1997).

differentiated on the basis of physiological traits. However, C. estertheticum and C. laramiense seem to have more characteristics in common with each other than with the strains from Antarctica. Distinguishing characteristics between $C$. estertheticum and C. laramiense are merely $\beta$-haemolysis on blood agar, utilization of glycogen and a higher temperature optimum for growth of the latter organism.

A further differentiation of strains was possible by analysis of fermentation end products formed after growth in peptone broth supplemented with $50 \mathrm{mM}$ glucose (Table 1). All strains formed a large amount of gas $\left(\mathrm{H}_{2}\right.$ and $\mathrm{CO}_{2}$, not quantified separately). Fatty acids formed by all strains were butyrate and lactate, but amounts varied considerably among strains. Strain DSM $14207^{\mathrm{T}}$ had a clearly distinct fermentation pattern, forming lactate and ethanol as major products, whereas all other strains produced butyrate as the dominant compound.

\section{Chemotaxonomic characteristics}

The cell wall peptidoglycan of all four novel strains from Antarctica contained meso-diaminopimelic acid as the diagnostic diamino acid (A $1 \gamma$ type according to the murein key of Schleifer \& Kandler, 1972). This murein structure is characteristic for the cluster I clostridia and was also found in the closely related C. estertheticum (Collins et al., 1992).

Cellular fatty acid patterns of the novel strains were determined and compared with the patterns of C. laramiense and $C$. estertheticum (Table 2). In all strains studied, fatty acids $\mathrm{C}_{14: 0}, \mathrm{C}_{16: 1} \omega 9 c, \mathrm{C}_{16: 0}$ and $\mathrm{C}_{16: 1} \omega 9 c$ dimethylacetal were among the major components. To analyse the influence of medium composition on the fatty acid pattern of C. estertheticum DSM $8809^{\mathrm{T}}$, the values obtained in Wilkins-Chalgren broth were compared with published data obtained from cells grown in PYG broth (Wilde et al., 1997). It turned out that the fatty acid profile of this strain is relatively stable and independent of cultivation medium. Thus, data taken from the literature for established species should be comparable with results obtained in this study for the novel strains. The fatty acid profiles of the Antarctica strains were clearly distinct from the profiles of $C$. laramiense, $C$. estertheticum and other related species of the genus Clostridium. The fatty acid $\mathrm{C}_{16: 1} \omega 9 c$ was the dominant component $(25 \cdot 4-30 \cdot 7 \%)$ in the novel strains, whereas the fatty acid $\mathrm{C}_{14: 0}(24 \cdot 7-34 \cdot 5 \%)$ was the most abundant component in the patterns of $C$. laramiense, $C$. estertheticum and Clostridium pascui (Wilde et al., 1997). The phylogenetically related Clostridium subterminale could be distinguished from the novel strains as it contained about 
Table 3. Genotypic differentiation of the four novel isolates, C. laramiense and C. estertheticum

Values in the upper right represent binary 16S rDNA similarity values (\%), whereas values in the lower left represent DNA-DNA reassociation values (\%). ND, Not determined. Each of strains DSM $14204^{\mathrm{T}}$ and DSM $14206^{\mathrm{T}}$ is represented by two distinct $16 \mathrm{~S}$ rDNA clone sequences, meaning that several binary similarity values were obtained. The first value given is based on clone 5 of strain DSM $14204^{\mathrm{T}}$ and clone 11 of strain DSM $14206^{\mathrm{T}}$; values in parentheses are based on the alternative clone sequences.

\begin{tabular}{|c|c|c|c|c|c|c|c|}
\hline Strain & $\begin{array}{c}\text { DNA G }+ \text { C } \\
\text { content }(\mathrm{mol} \%)\end{array}$ & 1 & 2 & 3 & 4 & 5 & 6 \\
\hline 1. C. frigoris DSM $14204^{\mathrm{T}}$ & $31 \cdot 9$ & - & $99 \cdot 1(98 \cdot 8)$ & $98 \cdot 4(98 \cdot 2,98 \cdot 0)$ & $97 \cdot 7(97 \cdot 8)$ & $99 \cdot 5(99 \cdot 2)$ & $99 \cdot 3(99 \cdot 2)$ \\
\hline 3. C. bowmanii DSM $14206^{\mathrm{T}}$ & $32 \cdot 0$ & 33 & 47 & - & $97 \cdot 0(96 \cdot 7)$ & $98 \cdot 7(98 \cdot 4)$ & $98 \cdot 6(98 \cdot 3)$ \\
\hline 4. C. psychrophilum DSM $14207^{\mathrm{T}}$ & $31 \cdot 8$ & 49 & 40 & 36 & - & $97 \cdot 7$ & $97 \cdot 7$ \\
\hline 5. C. laramiense ATCC $51254^{\mathrm{T}}$ & $32 \cdot 4$ & 62 & 34 & ND & ND & - & $99 \cdot 8$ \\
\hline
\end{tabular}

$20 \%$ iso- and anteiso-branched fatty acids (Wilde et al., 1997).

\section{Genotypic characteristics and phylogeny}

Genomic DNA was isolated from the novel strains, C. laramiense ATCC $51254^{\mathrm{T}}$ and C. estertheticum DSM $8809^{\mathrm{T}}$. The DNA base compositions of all strains were in the narrow range $31 \cdot 8-33 \cdot 9 \mathrm{~mol} \%$ (Table 3 ). Previously published $\mathrm{G}+\mathrm{C}$ values for DNAs of $C$. laramiense ATCC $51254^{\mathrm{T}}(28 \mathrm{~mol} \%)$ and C. estertheticum DSM $8809^{\mathrm{T}}$ (26 mol\%) were several mol\% below the values determined in this study. This is presumably because the thermal denaturation method used in previous studies can apparently lead to an underestimation of low $\mathrm{G}+\mathrm{C}$ values, in contrast to the direct quantification of DNA base compositions by HPLC.

In Table 3, the levels of DNA-DNA relatedness among the strains from Antarctica and the type strains of C. laramiense and C. estertheticum are shown. The novel strains shared DNA-DNA reassociation values below $50 \%$, thus clearly indicating their affiliation to different species according to the currently accepted species concept for prokaryotes (Stackebrandt \& Goebel, 1994; Rosselló-Mora \& Amann, 2001). A relatively high DNA-DNA reassociation value of $62 \%$ was obtained only between strain DSM $14204^{\mathrm{T}}$ and
C. laramiense ATCC $51254^{\mathrm{T}}$. This value is, however, still below the threshold of $70 \%$ for strains belonging to a single species (Wayne et al., 1987). On the other hand, the level of DNA-DNA binding between $C$. laramiense ATCC $51254^{\mathrm{T}}$ and C. estertheticum DSM $8809^{\mathrm{T}}$ was $79 \%$, indicating a close relationship between these strains at species level.

The genomic heterogeneity of all strains was further analysed by ribotyping. A dendrogram based on pattern similarity revealed three clusters (Fig. 2). The type strains of C. laramiense and C. estertheticum had nearly identical patterns and formed a tight cluster. Another cluster was formed by strains DSM $14205^{\mathrm{T}}$, DSM $14204^{\mathrm{T}}$ and DSM $14206^{\mathrm{T}}$, which are represented by patterns with a similarity value of more than $85 \%$. Strain DSM $14207^{\mathrm{T}}$ was separate from all other strains and represented the third cluster.

In the course of this study, almost complete 16S rRNA gene sequences of strains DSM $14204^{\mathrm{T}}$ (1477 nt), DSM $14206^{\mathrm{T}}(1474-1477 \mathrm{nt})$ and C. laramiense ATCC $51254^{\mathrm{T}}$ $(1473 \mathrm{nt})$ were determined. The sequences of strains DSM $14204^{\mathrm{T}}$ and DSM $14206^{\mathrm{T}}$ obtained previously (Brambilla et al., 2001) were only determined partially due to ambiguities in the $5^{\prime}$-terminal regions of the $16 \mathrm{~S}$ rRNA sequences. This was presumably caused by multiple operons. It was therefore necessary to clone $16 \mathrm{~S}$ rRNA

\section{Similarity [\%] $\quad$ Fragment size [kb]}
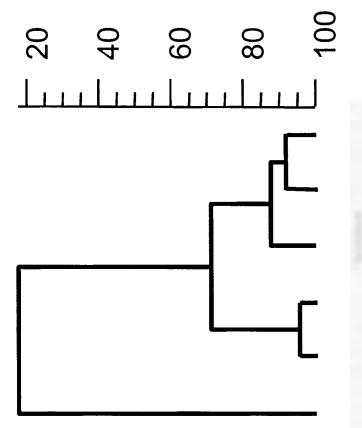

DSM $14205^{\top}$

DSM $14204^{\top}$

DSM $14206^{\top}$

DSM $8809^{\top}$

ATCC $51254^{\top}$

DSM $14207^{\top}$
Fig. 2. Diversity of normalized Pvull ribotype patterns of the novel strains from Antarctica, C. laramiense ATCC $51254^{\top}$ and C. estertheticum DSM $8809^{\top}$. The similarity dendrogram was generated using BIONUMERICS software (Applied Maths). 


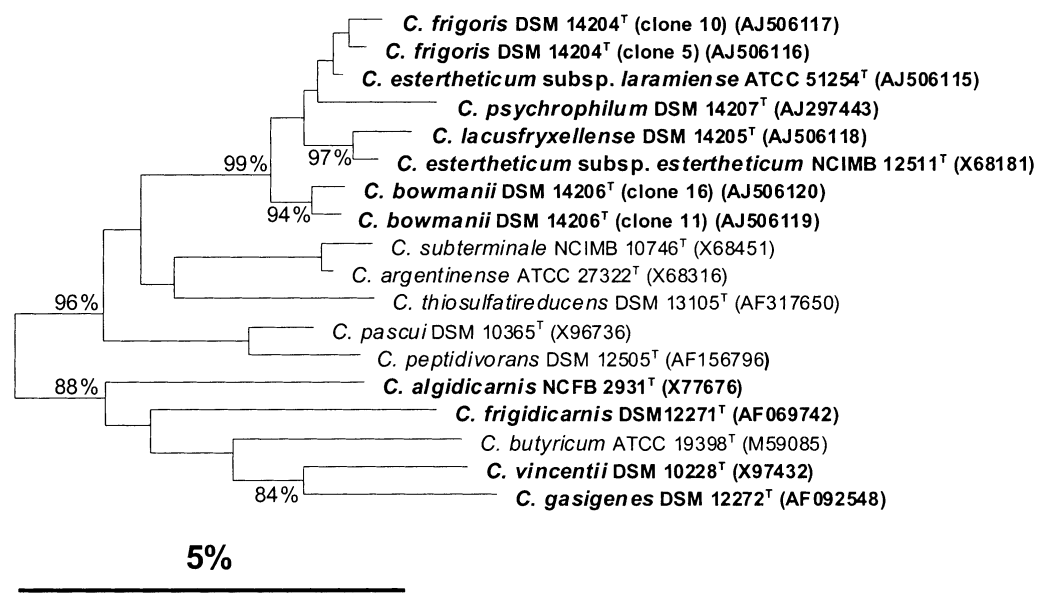

Fig. 3. Phylogenetic dendrogram, based on almost-complete 16S rRNA gene sequences, showing the position of the novel strains from Antarctica among representatives of cluster I clostridia. GenBank/EMBL accession numbers are given in parentheses. The selection of reference strains was based on either a close phylogenetic relationship to the novel strains or a psychrophilic or psychrotrophic phenotype (highlighted in bold). Clostridium butyricum is the type species of the genus. The tree was reconstructed using the neighbour-joining method (Saitou \& Nei, 1987). Phylogenetic distances were calculated as described by Jukes \& Cantor (1969). Bootstrap values above $80 \%$ (10000 bootstrap resamplings for each node) are shown at branching points. The sequence of Clostridium grantii (X75272) was used as an outgroup (not shown). Bar, $5 \%$ estimated sequence divergence.

genes of both strains prior to sequencing. A comparative sequence analysis of the cloned 16S rRNA genes revealed that each strain contained at least four to five distinct operon sequences. However, among the various 16S rRNA operons from each strain, the sequence heterogeneity was only limited (similarity values above 99\%) and was restricted to exchanges, insertions or deletions of single bases. Consequently, it seems justified to represent each of strains DSM $14204^{\mathrm{T}}$ and DSM $14206^{\mathrm{T}}$ by only two distinct operon sequences chosen from the respective clusters of cloned 16S rRNA genes. The hitherto unknown 16S rRNA sequence of $C$. laramiense was determined to clarify the phylogenetic relationship of this species with C. estertheticum, the two species sharing many phenotypic traits. The phylogenetic dendrogram in Fig. 3 illustrates that the novel strains from Antarctica cluster together with C. laramiense and $C$. estertheticum. The resulting branch is supported by high bootstrap values. The sequence diversity within this group ranges from 96.7 to $99 \cdot 8 \%$ (Table 3 ). In phylogenetic trees, the nearest neighbours of this cluster of psychrophiles are the mesophilic species C. subterminale, Clostridium argentinense and Clostridium thiosulfatireducens. On the other hand, $C$. vincentii, although a psychrophile isolated from Antarctica (Mountfort et al., 1997), is only distantly related and shares similarity values of around $90 \%$ to the corresponding $16 \mathrm{~S}$ rRNA gene sequences of the novel strains. The overall topology of the tree shown in Fig. 3 was stable when checked with various treeing algorithms; only some variation in the relative branching order of highly similar sequences ( $>99 \%$ ) became evident.

\section{Conclusions}

To our knowledge, among the species of clostridia with validly published names, only $C$. vincentii, C. laramiense and C. estertheticum are true psychrophiles. In contrast, several species that have been isolated from cold habitats (e.g. Clostridium arcticum, Clostridium algidicarnis, Clostridium frigidicarnis and Clostridium gasigenes) or normal habitats (e.g. Clostridium akagii, Clostridium fimetarium and Clostridium putrefaciens) are only psychrotrophic (psychrotolerant), having temperature optima around or above $20{ }^{\circ} \mathrm{C}$. Phylogenetically, the novel strains from Antarctica were most closely related to $C$. laramiense and C. estertheticum, both of which were isolated from refrigerated meat. C. vincentii, on the other hand, which was also isolated from a limnic site in Antarctica, was only distantly related to the strains under study. A detailed taxonomic investigation based on a polyphasic approach, including the type strains of $C$. laramiense and $C$. estertheticum, revealed that the novel strains do not belong to any currently described species and can be easily distinguished from each other. Therefore, it is proposed to regard the four isolates from Antarctica as novel Clostridium species; these are formally described below.

The close genotypic relationship found between C. estertheticum and C. laramiense suggests that these species should be united. C. estertheticum is retained as species designation, because it represents the oldest legitimate epithet. Some phenotypic traits, e.g. the presence of $\beta$-haemolysis on blood agar in C. laramiense, enable clear differentiation of the two type strains, so it is proposed to create two subspecies: C. laramiense is reclassified as C. estertheticum subsp. laramiense subsp. nov., and this consequently leads to the creation of $C$. estertheticum subsp. estertheticum subsp. nov.

\section{Description of Clostridium frigoris sp. nov.}

Clostridium frigoris (fri'go.ris. L. gen. n. frigoris of the cold).

Cells are rod-shaped $(1 \cdot 4-1 \cdot 8 \times 2 \cdot 2-5 \cdot 0 \mu \mathrm{m})$ and occur 
singly, in pairs or short chains. Filamentous cells are occasionally present, especially in cultures grown on agar plates. Motile by peritrichous flagella. Endospores are spherical and located at a terminal position; sporangium not swollen. Gram-positive. Colonies on sheep-blood agar are 1-2 $\mathrm{mm}$ in diameter, round with often coarsely granulated margins, smooth, slightly raised, cream-white to greyish, semi-transparent to opaque and non-haemolytic. The temperature optimum for growth is $5-7^{\circ} \mathrm{C}$; the upper limit is $11^{\circ} \mathrm{C}$. The $\mathrm{pH}$ range for growth is $5 \cdot 5-7 \cdot 5$ (optimum $6 \cdot 8-7 \cdot 2$ ). Under optimal conditions, the doubling time is $13 \cdot 0 \mathrm{~h}$. The following carbohydrates are utilized: amygdalin, arabinose, cellobiose, fructose, galactose, glucose, glycogen, inositol (weak), inulin, lactose, maltose, mannose, melibiose, raffinose, rhamnose, ribose (weak), salicin, starch, sucrose, trehalose and xylose. The following carbohydrates are not utilized: mannitol, melezitose and sorbitol. Gelatin and starch are not hydrolysed. The fermentation products formed are butyrate, formate, lactate, acetate, ethanol, hydrogen and carbon dioxide. The cell wall peptidoglycan contains meso-diaminopimelic acid. The major cellular fatty acids are $\mathrm{C}_{16: 1} \omega 9 c, \mathrm{C}_{16: 1} \omega 9 c$ dimethylacetal, $\mathrm{C}_{14: 0}$, $\mathrm{C}_{16: 0}, \mathrm{C}_{16: 1} \omega 11 \mathrm{c}$ and an unknown compound with an equivalent chain length of $14 \cdot 777-14 \cdot 783$. The G+C content of the DNA of the type strain is $31.9 \mathrm{~mol} \%$ (HPLC).

The type strain, strain D-1/D-an/II $\mathrm{I}^{\mathrm{T}}$ (=DSM $14204^{\mathrm{T}}$ $=$ ATCC BAA $-579^{\mathrm{T}}$ ), was isolated from a microbial mat sample taken from a moated area around Lake Fryxell, Antarctica.

\section{Description of Clostridium lacusfryxellense sp. nov.}

Clostridium lacusfryxellense (la'cus.fry.xel.len'se. N.L. neut. adj. lacusfryxellense of Lake Fryxell, the lake in Antarctica from which the type strain was isolated).

Cells are rod-shaped $(1 \cdot 0-1 \cdot 2 \times 2 \cdot 2-5 \cdot 0 \mu \mathrm{m})$ and occur singly, in pairs or short chains. Motile by peritrichous flagella. Endospores are spherical to slightly ellipsoidal and located at a terminal to subterminal position; sporangium is not swollen. Gram-positive. Colonies on sheep-blood agar are 1-2 $\mathrm{mm}$ in diameter, round with often coarsely granulated margins, smooth, slightly raised, cream-white to greyish, semi-transparent to opaque and non-haemolytic. The temperature optimum for growth is $8-12{ }^{\circ} \mathrm{C}$; the upper limit is $15^{\circ} \mathrm{C}$. The $\mathrm{pH}$ range for growth is $6 \cdot 0-7 \cdot 3$ (optimum 6:6-7:1). Under optimal conditions, the doubling time is $10 \cdot 7 \mathrm{~h}$. The following carbohydrates are utilized: amygdalin, cellobiose, fructose, galactose, glucose, glycogen, inositol, inulin, lactose, mannitol, melezitose, melibiose, raffinose, ribose, salicin, starch, sucrose, trehalose and xylose. The following carbohydrates are not utilized: arabinose, maltose, mannose, rhamnose and sorbitol. Gelatin and starch are not hydrolysed. The fermentation products formed are butyrate, formate, acetate, lactate, ethanol, hydrogen and carbon dioxide. The cell wall peptidoglycan contains meso-diaminopimelic acid. The major cellular fatty acids are $\mathrm{C}_{16: 1} \omega 9 c, \mathrm{C}_{16: 1} \omega 9 c$ dimethylacetal, $\mathrm{C}_{14: 0}$, $\mathrm{C}_{16: 1} \omega 7 c, \mathrm{C}_{16: 0}$ and $\mathrm{C}_{16: 1} \omega 11 c$. The $\mathrm{G}+\mathrm{C}$ content of the DNA of the type strain is $32 \cdot 1 \mathrm{~mol} \%$ (HPLC).

The type strain, strain $\mathrm{C} / \mathrm{C}-\mathrm{an} / \mathrm{B} 1^{\mathrm{T}} \quad\left(=\mathrm{DSM} \quad 14205^{\mathrm{T}}\right.$ $=$ ATCC BAA $-580^{\mathrm{T}}$ ), was isolated from a microbial mat sample taken from a moated area around Lake Fryxell, Antarctica.

\section{Description of Clostridium bowmanii sp. nov.}

Clostridium bowmanii (bow.ma' ni.i. N.L. gen. n. bowmanii referring to Bowman, in honour of the microbiologist John P. Bowman, who has made important contributions to our knowledge of the diversity of psychrophilic bacteria).

Cells are rod-shaped $(1 \cdot 0-1 \cdot 2 \times 2 \cdot 0-8 \cdot 0 \mu \mathrm{m})$ and occur singly, in pairs or short chains. Motile by peritrichous flagella. In cultures grown on solid media, filamentous cells are frequently present. Endospores are spherical and located in a terminal to subterminal position; sporangium is not or slightly swollen. Gram-positive. Colonies on sheep-blood agar are 1-2 $\mathrm{mm}$ in diameter, round with often coarsely granulated margins, smooth, slightly raised, cream-white to greyish, semi-transparent to opaque and non-haemolytic. The temperature optimum for growth is $12-16^{\circ} \mathrm{C}$; the upper limit is $20^{\circ} \mathrm{C}$. The $\mathrm{pH}$ range for growth is $5 \cdot 6-$ $7 \cdot 4$ (optimum $6 \cdot 8-7 \cdot 2$ ). Under optimal conditions, the doubling time is $8.4 \mathrm{~h}$. The following carbohydrates are utilized: fructose, galactose, glucose, inulin, maltose, mannose, ribose (weak), salicin, sucrose, trehalose and xylose. The following carbohydrates are not utilized: amygdalin, arabinose, cellobiose, glycogen, inositol, lactose, mannitol, melezitose, melibiose, raffinose, rhamnose, sorbitol and starch. Gelatin and starch are not hydrolysed. The fermentation products formed are butyrate, acetate, formate, ethanol, lactate, 1-butanol, hydrogen and carbon dioxide. The cell wall peptidoglycan contains mesodiaminopimelic acid. The major cellular fatty acids are $\mathrm{C}_{16: 1} \omega 9 c, \mathrm{C}_{14: 0}, \mathrm{C}_{16: 1} \omega 9 c$ dimethylacetal, $\mathrm{C}_{16: 0}, \mathrm{C}_{16: 1} \omega 11 c$ and $\mathrm{C}_{16: 1} \omega 7 c$. The $\mathrm{G}+\mathrm{C}$ content of the DNA of the type strain is $32 \cdot 0 \mathrm{~mol} \%$ (HPLC).

The type strain, strain A-1/C-an/C1 ${ }^{\mathrm{T}}$ (=DSM $14206^{\mathrm{T}}$ $=$ ATCC BAA- $581^{\mathrm{T}}$ ), was isolated from a microbial mat sample taken from a moated area around Lake Fryxell, Antarctica.

\section{Description of Clostridium psychrophilum sp. nov.}

Clostridium psychrophilum (psy.chro'phi.lum. Gr. adj. psychros cold; Gr. adj. philos loving; N.L. neut. adj. psychrophilum cold-loving).

Cells are rod-shaped $(1 \cdot 0-1 \cdot 4 \times 2 \cdot 5-8 \cdot 0 \mu \mathrm{m})$ and occur singly, in pairs or short chains. Motile by peritrichous flagella. In cultures grown on solid media, filamentous cells are frequently present. Endospores are ellipsoidal and located in a subterminal to terminal position; sporangium 
is not swollen. Gram-positive. Colonies on sheep-blood agar are 1-2 $\mathrm{mm}$ in diameter, round with often coarsely granulated margins, smooth, slightly raised, cream-white to greyish, semi-transparent to opaque and non-haemolytic. The temperature optimum for growth is $4{ }^{\circ} \mathrm{C}$; the upper limit is $10^{\circ} \mathrm{C}$. The $\mathrm{pH}$ range for growth is $5 \cdot 5-7 \cdot 5$ (optimum $6 \cdot 5-7 \cdot 0)$. Under optimal conditions, the doubling time is $33.9 \mathrm{~h}$. The following carbohydrates are utilized: arabinose, cellobiose, fructose, glucose, inulin, maltose, mannose, sucrose, trehalose and xylose. The following carbohydrates are not utilized: amygdalin, galactose, glycogen, inositol, lactose, mannitol, melezitose, melibiose, raffinose, rhamnose, ribose, salicin, sorbitol and starch. Gelatin and starch are not hydrolysed. The fermentation products formed are lactate, ethanol, 1-butanol, butyrate, hydrogen and carbon dioxide. The cell wall peptidoglycan contains mesodiaminopimelic acid. The major cellular fatty acids are $\mathrm{C}_{16: 1} \omega 9 c, \mathrm{C}_{14: 0}, \mathrm{C}_{16: 1} \omega 9 c$ dimethylacetal, $\mathrm{C}_{16: 1} \omega 11 c$ and $\mathrm{C}_{16: 0}$. The $\mathrm{G}+\mathrm{C}$ content of the DNA of the type strain is $31 \cdot 8 \mathrm{~mol} \%$ (HPLC).

The type strain, strain A-1/C-an/ $\mathrm{I}^{\mathrm{T}}$ (=DSM $14207^{\mathrm{T}}$ $=$ ATCC BAA $-582^{\mathrm{T}}$ ), was isolated from a microbial mat sample taken from a moated area around Lake Fryxell, Antarctica.

\section{Emended description of Clostridium estertheticum Collins et al. 1992}

The emendation of the species description is based on the results of this study and the publication of Kalchayanand et al. (1993). Cells are rod-shaped $(1 \cdot 3-1 \cdot 5 \times 2 \cdot 4-6 \cdot 0 \mu \mathrm{m})$ and occur singly, in pairs or short chains. Motile by peritrichous flagella. Endospores are ellipsoidal and located mainly in a subterminal position, but sometimes also terminal or central; sporangium is slightly swollen. Grampositive. Colonies on sheep-blood agar are 1-2 $\mathrm{mm}$ in diameter, round with often coarsely granulated margins, smooth, slightly raised, cream-white to greyish and semitransparent to opaque. Psychrophilic. The $\mathrm{pH}$ optimum is around $\mathrm{pH} 6 \cdot 5$. The following carbohydrates are utilized: arabinose, cellobiose, fructose, galactose, glucose, inositol, inulin, maltose, mannitol, mannose, melibiose, raffinose, rhamnose, salicin, sorbitol, starch, sucrose and xylose. The following carbohydrates are not utilized: amygdalin, lactose, melezitose, ribose and trehalose. Starch is hydrolysed, but gelatin is not. The fermentation products formed are butyrate, acetate, lactate, formate, 1-butanol, ethanol, hydrogen and carbon dioxide. The cell wall peptidoglycan contains meso-diaminopimelic acid. The major cellular fatty acids are $\mathrm{C}_{14: 0}, \mathrm{C}_{16: 1} \omega 9 c$ dimethylacetal, $\mathrm{C}_{16: 1} \omega 9 c, \mathrm{C}_{16: 0}$, $\mathrm{C}_{16: 1} \omega 11 \mathrm{c}$ and an unknown compound with an equivalent chain length of $14 \cdot 777-14 \cdot 783$. The $\mathrm{G}+\mathrm{C}$ content of the DNA of the type strain is $32 \cdot 4-33.9 \mathrm{~mol} \%$ (HPLC).

The type strain is NCIMB $12511^{\mathrm{T}}\left(=\mathrm{DSM} 8809^{\mathrm{T}}\right)$, isolated from vacuum-packaged refrigerated meat.
Description of Clostridium estertheticum subsp. laramiense subsp. nov., comb. nov.

Clostridium estertheticum subsp. laramiense (la.ra.mi.en'se. N.L. neut. adj. laramiense referring to the city of Laramie, WY, USA).

Basonym: Clostridium laramiense Kalchayanand et al. 1993.

The original description was given by Kalchayanand et al. (1993). In contrast to the original description, it was found in this study that arabinose, cellobiose and xylose can be utilized as substrates. The following distinguishing traits allow differentiation from $C$. estertheticum subsp. estertheticum: colonies on sheep-blood agar are $\beta$-haemolytic; temperature optimum for growth is $15^{\circ} \mathrm{C}$, the upper limit is $21^{\circ} \mathrm{C}$; pH range for growth is $4 \cdot 5-7 \cdot 5$ (optimum $6 \cdot 5$ ); glycogen is utilized; and, in PYG broth, the most abundant non-gaseous fermentation end products are butyrate, 1-butanol and lactate. The $\mathrm{G}+\mathrm{C}$ content of the DNA of the type strain is $32 \cdot 4 \mathrm{~mol} \%$ (HPLC).

The type strain is ATCC $51254^{\mathrm{T}}\left(=\mathrm{DSM} 14864^{\mathrm{T}}\right)$.

\section{Description of Clostridium estertheticum subsp. estertheticum subsp. nov.}

According to Rule 40d of the Code, the description of C. estertheticum subsp. laramiense subsp. nov. automatically creates another subspecies, C. estertheticum subsp. estertheticum Collins et al. 1992. In addition to the characteristics mentioned in the emended description of $C$. estertheticum, the following distinguishing traits allow identification of this subspecies: colonies on sheep-blood agar are non-haemolytic; temperature optimum for growth is $6-8{ }^{\circ} \mathrm{C}$, the upper limit is $13^{\circ} \mathrm{C}$; $\mathrm{pH}$ range for growth is $5 \cdot 5-7 \cdot 8$ (optimum $6 \cdot 5-7 \cdot 2$ ); glycogen cannot be utilized; and, in PYG broth, the most abundant non-gaseous fermentation end products are volatile fatty acids (butyrate, acetate and formate). The $\mathrm{G}+\mathrm{C}$ content of the DNA of the type strain is $33.9 \mathrm{~mol} \%$ (HPLC).

The type strain is NCIMB $12511^{\mathrm{T}}\left(=\mathrm{DSM} 8809^{\mathrm{T}}\right)$.

\section{ACKNOWLEDGEMENTS}

The excellent technical assistance of Ulrike Steiner, Anika Vester and Jola Swiderski is acknowledged. This study was supported in part by grant BIO4CT 980040 (MICROMAT) and in part by grant QLK2-CT2001-01267 (genus Clostridium), both from the European Union.

\section{REFERENCES}

Brambilla, E., Hippe, H., Hagelstein, A., Tindall, B. J. \& Stackebrandt, E. (2001). 16S rDNA diversity of cultured and uncultured prokaryotes of a mat sample from Lake Fryxell, McMurdo Dry Valleys, Antarctica. Extremophiles 5, 23-33.

Bruce, J. L. (1996). Automated system rapidly identifies and characterizes microorganisms in food. Food Technol 50, 77-81. 
Cashion, P., Holder-Franklin, M. A., McCully, J. \& Franklin, M. (1977). A rapid method for the base ratio determination of bacterial DNA. Anal Biochem 81, 461-466.

Collins, M. D., Rodrigues, U. M., Dainty, R. H., Edwards, R. A. \& Roberts, T. A. (1992). Taxonomic studies on a psychrophilic Clostridium from vacuum-packed beef: description of Clostridium estertheticum sp. nov. FEMS Microbiol Lett 96, 235-240.

Collins, M. D., Lawson, P. A., Willems, A., Cordoba, J. J., FernandezGarayzabal, J., Garcia, P., Cai, J., Hippe, H. \& Farrow, J. A. E. (1994). The phylogeny of the genus Clostridium: proposal of five new genera and eleven new species combinations. Int J Syst Bacteriol 44, 812-826.

De Ley, J., Cattoir, H. \& Reynaerts, A. (1970). The quantitative measurement of DNA hybridization from renaturation rates. Eur J Biochem 12, 143-153.

DSMZ (2001). Catalogue of Strains, 7th edn. Braunschweig: Deutsche Sammlung von Mikroorganismen und Zellkulturen.

Frühling, A., Schumann, P., Hippe, H., Sträubler, B. \& Stackebrandt, E. (2002). Exiguobacterium undae sp. nov. and Exiguobacterium antarcticum sp. nov. Int J Syst Evol Microbiol 52, 1171-1176.

Heimbrook, M. E., Wang, W. L. L. \& Campbell, G. (1989). Staining bacterial flagella easily. J Clin Microbiol 27, 2612-2615.

Holdeman, L. V., Cato, E. P. \& Moore, W. E. C. (1977). Anaerobe Laboratory Manual, 4th edn. Blacksburg, VA: Virginia Polytechnic Institute and State University.

Hungate, R. E. (1950). The anaerobic mesophilic cellulolytic bacteria. Bacteriol Rev 14, 1-49.

Huß, V. A. R., Festl, H. \& Schleifer, K. H. (1983). Studies on the spectrophotometric determination of DNA hybridization from renaturation rates. Syst Appl Microbiol 4, 184-192.

Jahnke, K. D. (1992). Basic computer program for evaluation of spectroscopic DNA renaturation data from GILFORD System 2600 spectrometer on a PC/XT/AT type personal computer. J Microbiol Methods 15, 61-73.

Jukes, T. H. \& Cantor, C. R. (1969). Evolution of protein molecules. In Mammalian Protein Metabolism, vol. 3, pp. 21-132. Edited by H. N. Munro. New York: Academic Press.

Kalchayanand, N., Ray, B. \& Field, R. A. (1993). Characteristics of psychrotrophic Clostridium laramie causing spoilage of vacuumpackaged refrigerated fresh and roasted beef. J Food Prot 56, 13-17.

Kämpfer, P. \& Kroppenstedt, R. M. (1996). Numerical analysis of fatty acid patterns of coryneform bacteria and related taxa. Can J Microbiol 42, 989-1005.

Kroppenstedt, R. M. (1985). Fatty acid and menaquinone analysis of actinomycetes and related organisms. In Chemical Methods in Bacterial Systematics, pp. 173-179. Edited by M. Goodfellow \& D. E. Minnikin. London: Academic Press.
Lang, E. \& Lang, H. (1972). Spezifische Farbreaktion zum direkten Nachweis der Ameisensäure. Z Anal Chem 260, 8-10.

Mesbah, M., Premachandran, U. \& Whitman, W. B. (1989). Precise measurement of the $\mathrm{G}+\mathrm{C}$ content of deoxyribonucleic acid by high-performance liquid chromatography. Int J Syst Bacteriol 39, 159-167.

Miller, L. T. (1982). Single derivatization method for routine analysis of bacterial whole-cell fatty acid methyl esters, including hydroxy acids. J Clin Microbiol 16, 584-586.

Morita, R. Y. (1975). Psychrophilic bacteria. Bacteriol Rev 39, 144-167.

Mountfort, D. O., Rainey, F. A., Burghardt, J., Kaspar, H. F. \& Stackebrandt, E. (1997). Clostridium vincentii sp. nov., a new obligately anaerobic, saccharolytic, psychrophilic bacterium isolated from low-salinity pond sediment of the McMurdo Ice Shelf, Antarctica. Arch Microbiol 167, 54-60.

Rainey, F. A., Ward-Rainey, N., Kroppenstedt, R. M. \& Stackebrandt, E. (1996). The genus Nocardiopsis represents a phylogenetically coherent taxon and a distinct actinomycete lineage: proposal of Nocardiopsaceae fam. nov. Int J Syst Bacteriol 46, 1088-1092.

Ratkowsky, D. A., Olley, J., McMeekin, T. A. \& Ball, A. (1982). Relationship between temperature and growth rate of bacterial cultures. J Bacteriol 149, 1-5.

Rosselló-Mora, R. \& Amann, R. (2001). The species concept for prokaryotes. FEMS Microbiol Rev 25, 39-67.

Saitou, N. \& Nei, M. (1987). The neighbor-joining method: a new method for reconstructing phylogenetic trees. Mol Biol Evol 4, 406-425.

Sasser, M. (1990). Identification of bacteria by gas chromatography of cellular fatty acids. Technical Note 101. Newark, DE: MIDI.

Schleifer, K. H. \& Kandler, O. (1972). Peptidoglycan types of bacterial cell walls and their taxonomic implications. Bacteriol Rev 36, 407-477.

Stackebrandt, E. \& Goebel, B. M. (1994). Taxonomic note: a place for DNA-DNA reassociation and 16S rRNA sequence analysis in the present species definition in bacteriology. Int J Syst Bacteriol 44, 846-849.

Steer, T., Collins, M. D., Gibson, G. R., Hippe, H. \& Lawson, P. A. (2001). Clostridium hathewayi sp. nov., from human faeces. Syst Appl Microbiol 24, 353-357.

Wayne, L. G., Brenner, D. J., Colwell, R. R. \& 9 other authors (1987). International Committee on Systematic Bacteriology. Report of the ad hoc committee on reconciliation of approaches to bacterial systematics. Int J Syst Bacteriol 37, 463-464.

Wilde, E., Collins, M. D. \& Hippe, H. (1997). Clostridium pascui sp. nov., a new glutamate-fermenting sporeformer from a pasture in Pakistan. Int J Syst Bacteriol 47, 164-170. 